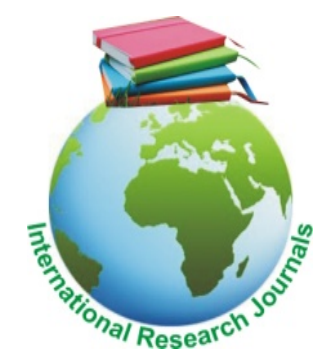

International Research Journal of Geology and Mining (IRJGM) (2276-6618) Vol. 4(2) pp. 064-076,

February, 2014

DOI: http:/dx.doi.org/10.14303/irjgm.2012.034

Available online http://www.interesjournals.org/irjgm

Copyright@2014 International Research Journals

Full Length Research Paper

\title{
Vertical Electrical Sounding and Groundwater Monitoring in a Tank Farm of Crude Oil Loading Terminal in Delta State, Nigeria
}

\author{
Okareh O.T ${ }^{1}$, Aigbedion Imuwahen Priscilla ${ }^{2}$ \\ ${ }^{1}$ Department of Environmental Health Sciences, Faculty of Public Health, \\ University of Ibadan, Ibadan, Oyo State, Nigeria \\ ${ }^{2}$ Centre for Health, Environment and Safety Studies, ${ }^{C} / 0{ }^{1}$ Department of Environmental Health Sciences, Faculty of \\ Public Health, University of Ibadan, Ibadan, Oyo State, Nigeria \\ ${ }^{*}$ Corresponding Author E-mail: dapsy2001@yahoo.co.uk
}

Abstract

\begin{abstract}
This study involves a geo-electrical investigation and groundwater monitoring of crude oil loading terminal in Delta state, Nigeria. Ten Vertical Electrical soundings (VES) were carried out across the area using the Schlumberger electrode array configuration, with maximum-current electrode separation $(A B / 2)$ of $100 \mathrm{~m}$. Interactive computer interpretations indicate a three geo-electric layer model case for all the curves. Root mean square (RMS) errors of between 2.23 and $8.11 \%$ were achieved. The number of resistivity of layers range from $71 \Omega \mathrm{m}$ to $306 \Omega \mathrm{m}$ for the first layer, while the second layer range from $19 \Omega \mathrm{m}$ to $75 \Omega \mathrm{m}$ and the third layer gave a range of $19 \Omega \mathrm{m}$ to $300 \Omega \mathrm{m}$. Curve types and resistivity values indicated a five $\mathrm{H}$ type curve which confirms that there is groundwater pollution and a $\mathrm{Q}$ type. Inventory of soil and ground water samples were also carried out by well/borehole drilling within bund walls of the storage tank for groundwater monitoring. Field studies and laboratory analytical results showed that soils of borehole cuttings are predominantly sandy and acidic. The total suspended solid ranged from $7.9-24.0 \mathrm{mg} / \mathrm{l}$ and iron concentrations ranged from $0.90-2.56 \mathrm{mg} / \mathrm{l}$, which were above the WHO recommended value for portable water.
\end{abstract}

Keywords: Vertical Electrical sounding, ground water monitoring wells, resistivity, bund walls.

\section{INTRODUCTION}

Environmental sustainability is one of the millennium development goals (MDGs) and groundwater quality management is very much connected to this goal (UNEP GEMS/water programme). Groundwater is the part of precipitation that seeps down through the soil until it reaches rock material that is saturated with water (Dingman, 2002). Using gravitational force, groundwater slowly moves underground at a downward angle, and may eventually seep into streams, lakes and oceans. Groundwater is considered very important natural resources. It provides a reasonable percentage of public water supplies. In Nigeria, most rural population supply their own drinking water from domestic wells. As such, ground water preservation and conservation is of paramount importance. Groundwater monitoring is a process design to determine the effects of human activities or operations on the groundwater aquifers and the soil layers bearing such water resource (Fetter 1994, Chapman 1992). It provides the data to measure improvement in environmental performance.

Groundwater contamination can come from a variety of residential, commercial or industrial sources. Oil and gas exploration and production activities can result in soil and groundwater contamination. This calls for the need to make an inventory of soil and groundwater contamination. The aims are to safeguard health and safety, minimise damage to the environment and assess potential for long term liabilities. Determining the source of groundwater contamination may resolve who is liable 
For expensive investigation and remediation costs. A properly operated facility, as well as a sound and appropriately documented groundwater monitoring program, is the first line of defence to reduce the costs associated with groundwater remediation efforts.

The study of water chemistry gives important indications of the geologic history of the enclosing rocks. However attempts in the area of groundwater quality and its flow system have mainly been restricted to the sedimentary basins. Therefore, detailed investigations of the groundwater potential and resources in this area, vis-àvis the industrial activities within the area in the past and present is imperative.

Hydro-geological investigations identify features like location, dynamic, distribution and chemical quality of groundwater including the characteristics of the aquifers and impermeable rock structures. It is on this basis that this study was conducted to carry out a groundwater monitoring and a geo-electrical investigation of the study area. The investigation, using vertical electrical sounding (VES), was designed to probe the near subsurface formation around the tank farm. The VES technique has been widely employed in solving groundwater challenges. For instance it has been applied in the study of delineation of groundwater contamination (Akaniyen et al, 2009; Abdullahi et al., 2011; Ugwu and Nwosu, 2009; Enikanselu, 2008). Its other application areas cut across exploration of geothermal reservoirs (Cid-fernandez and Araujo, 2007); groundwater exploration in hard rock (Nwankwo, 2011; K' Orowe et al, 2011; Armada et al 2009,Ariyo and Adeyemi, 2009) determination of boundary of saline and fresh water zones intrusion (Sinkadar et al;2010; Hodlur et al., 2010; Adeoti et al, 2010); estimation of acquifer specific yield ((Onu, 2003), estimation of hydraulic conductivity and transmissivity of aquifer (Ekwe et al; Egbai, 2011; Majumdar and Das, 2011; Tizro et al, 2010).The VES method has also been used in determination of zones with high yield potential in aquifer(Ailan adn Kumar; 2011; Goerge et al., 2011; Joshua et al,2011;Nejad, 2009), among others.

The objectives of this study are to ascertain that there are no unwanted or unforeseen spreading of contaminants into soil and groundwater from industrial activities; electrical sounding of the terminal for the installation of the monitoring wells for lithology / stratigraphy study; collection of the hydro-geological data; assessment of soil and groundwater quality through laboratory analysis of the groundwater samples. It is expected that data generated from the study would be used to recommend measures to correct hydrogeological stressors identified and utilize in further research.

\section{MATERIALS AND METHODS}

\section{Site description}

The specific study area for the installation of the monitoring wells is the Tank Farm area in an up-graded crude oil loading located within the Forcados areas of Niger Delta. Forcados is located in the distal distributary network of the Niger River Delta System, along the Forcados River, $65 \mathrm{~km}$ southwest of Warri. The area is within the tidal influence, partly submerged during the flood season of the meandering streams of the Forcados River and Odimodi Creek. Vegetation type within the general area is mangrove, backed by oil palm. Average annual rainfall is $380 \mathrm{~cm}$. Its general geology falls within the Coastal Swamp Depo-belt of the Niger Delta Basin. The Niger Delta Basin extends from about longitude $3^{\circ}$ $9^{\circ} \mathrm{E}$ and latitude $4^{\circ} 30^{\prime}-5^{\circ} 20^{\prime} \mathrm{N}$. Three chronostratigraphic units have been identified as constituting the sedimentary build-up of the basin (Short and Stauble, 1967; Allen, 1965). Sediment thickness is in excess of $8000 \mathrm{~m}$ (24000ft) in the central portion of the basin. These units are the Benin formation (Oligocene - Recent), Agbada formation (Oligocene - Recent) and Akata formation (Eocene recent). Overlying these sequences in most of the southern parts of the basin are Quaternary deposits, comprising four geomorphic units which is made up of a Deltaic Plain Belt characterized by fine to coarse-grained sand/ sandstone and clays; Freshwater Swamps and Meander Belts which is attributed with a top grey-black organic clay or silty clay overlying a predominantly sandy lithology with intercalating clay; The Saltwater Mangrove Swamp Belt associated with top layer of black silty clay I clay underlain by a predominantly sandy lithology intercalated with clay; and Coastal Islands and Beach Ridges that is predominated by sandy lithology with gravely interbeds in the deeper horizons (Wigwe, 1975).

\section{Geo-electrical survey}

Vertical Electrical Sounding has its principal use in the investigation of formation resistivity with depth. This is achieved by increasing the distance between the current electrodes so that the depth range to which the current penetrates increases. A succession of apparent resistivity readings was taken for increasing electrode spacing. The principle involves measuring current and potential difference and displaying their ratio as the measured resistance (in ohms). The instrumentation used include an ABEM terrameter which consists of two (2) portable units, the SAS $300 \mathrm{C}$ (a sequence averaging system) and the SAS 2000 Booster. The booster aids the SAS 300C to achieve better current penetration. This method is well documented in Telford et.al., 1976; and Zohdy et.al., 1974.

The readings measured by the terrameter were then 
recorded on a standard field data sheet at each current electrode spread position for subsequent analyses and interpretation. Stainless and sensitive steel electrodes which are driven into the ground several centimetres for good contact were also used in the study. Three reels of insulated light weight cables; two for current and one for potential electrodes was employed and the reels were attached to the current and potential terminals on the terrameter and to the appropriate electrodes at the other end.GPS was used to ascertain accurate coordinates of the stations.

Choice of electrode configuration is often based on consideration of ease of measurement, time available, depth of investigation, sensitivity to lateral variations and anomaly resolution. The Schlumberger configuration was adopted for this study because it is relatively unaffected by lateral variations in resistivity. The current electrodes were spaced much further apart than the potential electrodes. The current electrode spacing $(A B / 2)$ were progressively increased at six (6) points per decade while potential electrode spacing (MN/2) was kept constant. However, the potential electrode spacing was increased when the readings became too small to be accommodated by the instrument's sensitivity. Care was taken to keep the potential electrode to current electrode spacing ratio close to $1: 5$. For this study, equidistant spacing at six points per decade was used: 1.0, 1.47, $2.15,3.16,4.64,6.81,10.0,14.7,21.5,31.6,46.4,68.1$ and 100.0 .

Finally, ten vertical electrical soundings were done with a maximum current electrode spread $(A B / 2)$ of $100 \mathrm{~m}$. For quality assurance ad check, terrameter was calibrated to ensure accuracy of readings, prevention of crosspolarization by ensuring that the cables did not cross, proper inspections of sites to ensure stations are located away from cables and pipes and by making sure that all connections and disconnections are done only when the terrameter is switched off.

\section{Procedures for borehole drilling}

Thirty boreholes were drilled within the bund walls of crude oil storage tank 1- 10 for groundwater monitoring and for sub-surface Stratigraphy / Lithology investigation. The percussion drilling method was used to drill the boreholes. This method produces uncontaminated samples as no external drilling fluid is used. Soils cuttings at desired depths were collected for in-situ strata description in a field notebook, and portions were collected in labelled polythene bags, preserved for subsequent laboratory analysis. Core samples (Soil cuttings) were obtained at a regular interval to the required depth at each borehole point for stratigraphic log description. On reaching the desired aquifer depth, each borehole was cased using 4-inch (100mm) PVC casing worn with a threaded PVC screen attached and tightened to the lower end. This procedure was carried out in all the boreholes. The boreholes were then flushed and allowed to stay for about 48 hours to attain equilibrium. Water samples were collected in appropriate and labelled containers. In-situ parameters of $\mathrm{pH}$, and Dissolved Oxygen (DO) were measured immediately. Water samples for other parameters analysis were collected in appropriate containers, labelled, and preserved (after fixing for heavy metals) in iced packed coolers for onward transportation and laboratory analysis. Static water levels were measured and all the completed boreholes were properly 'capped'. Prior to collecting the groundwater samples, each container was first rinsed with distilled water. An elevated surface pad using cement and granites was constructed to facilitate drainage away from the well installation and to prevent pool of water in the immediate vicinity. The cement basement was made to hold firmly the attached protective metal-casing with provision for lock and key. Each borehole was covered with screen at the top of the PVC pipe, properly painted and labelled for easy identification on the metal-casing. Each borehole was properly geo-referenced using a portable Global Positioning System (GPS) handset. A field-laboratory samples handling chain of custody was maintained for all the drill soil cuttings and groundwater sample.

\section{Soil data collection}

From the borehole cuttings, nine core samples were collected. The soil $\mathrm{pH}$ was determined in water $(1: 1$ soil to water ratio), with the aid of a Glass electrode $\mathrm{pH}$ meter. The $\mathrm{pH}$ meter was calibrated with $\mathrm{pH} 7.0$ and $\mathrm{pH}$ 4.0 buffer standards before use. Nitrate- nitrogen was determined in soils extracts obtained by shaking $5 \mathrm{~g}$ of a representative soil sample with $50 \mathrm{ml}$ of $\mathrm{K}_{2} \mathrm{SO}_{4}$. Aliquot of this extract was used for the determination of nitratenitrogen by titrating with phenol-disulphonic acid. Available phosphorus in soil was determined by the Bray No. 1 method (Bray and Kurtz, 1945). Exchangeable Na+ in soil samples was determined as described by Black (1965). Flame photometry was used to determine potassium and sodium from supernatant. Sulphate was determined by weighing five grammes $(5 \mathrm{~g})$ of soil into a centrifuge tube. This was followed by the addition of $25 \mathrm{ml}$ of $\mathrm{KH}_{2} \mathrm{PO}_{4}$ (extracting solution) and shaken for 30 minutes on a mechanical shaker. The suspension was centrifuged and $\mathrm{SO}_{4}{ }^{2-}$ content in solution was determined by turbidimetry method. The percent transmitancy and optical density were determined at $420 \mathrm{~nm}$ using electrocolorimeter. Total Petroleum Hydrocarbon (TPH) was determined using Department of Petroleum Resources (DPR) recommended methods from ASTM, USEPA and APHA. These can be found in DPR guidelines part III (Appendix VIII-D2). The hydrocarbon content of soils (soil and grease) was determined by the spectrophotometric 

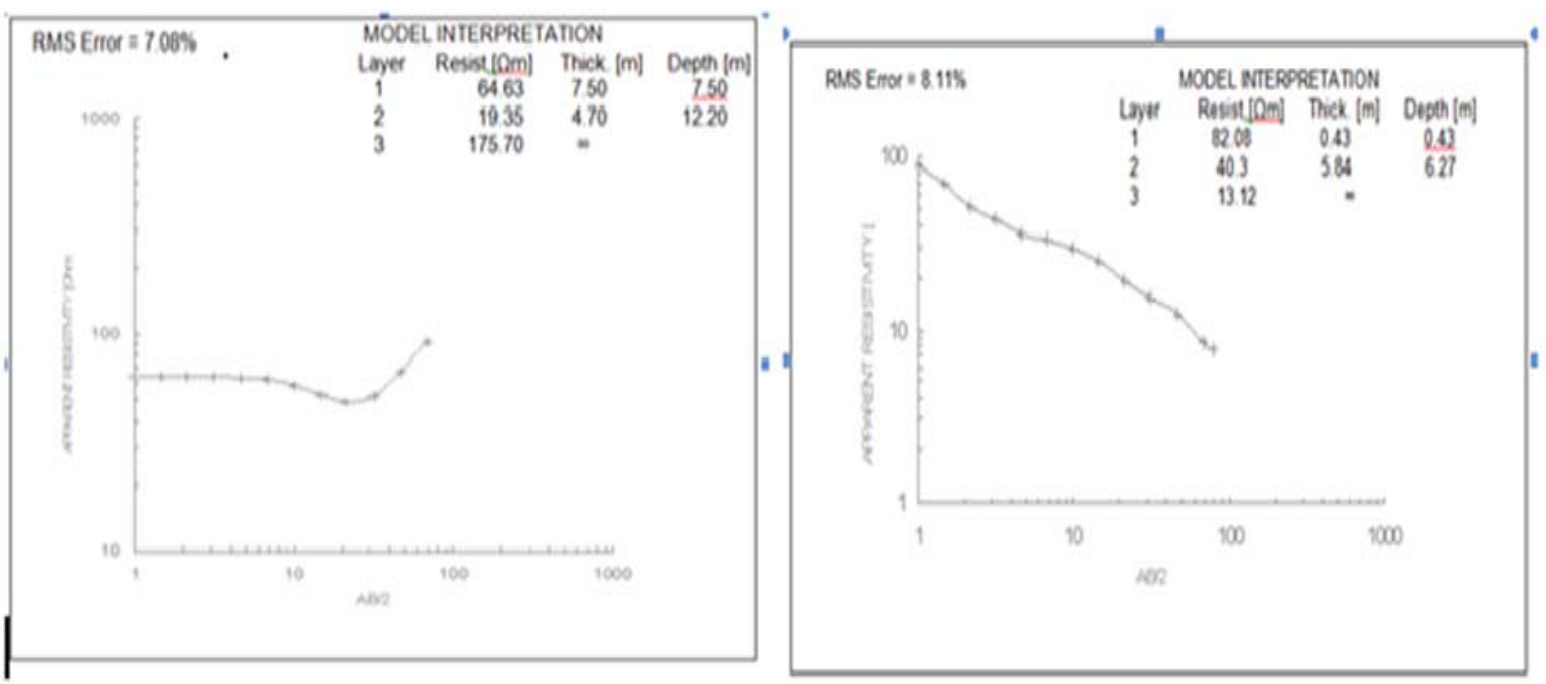

Figure 1. Showing FCD-1 and FCD-2 (from left to right)
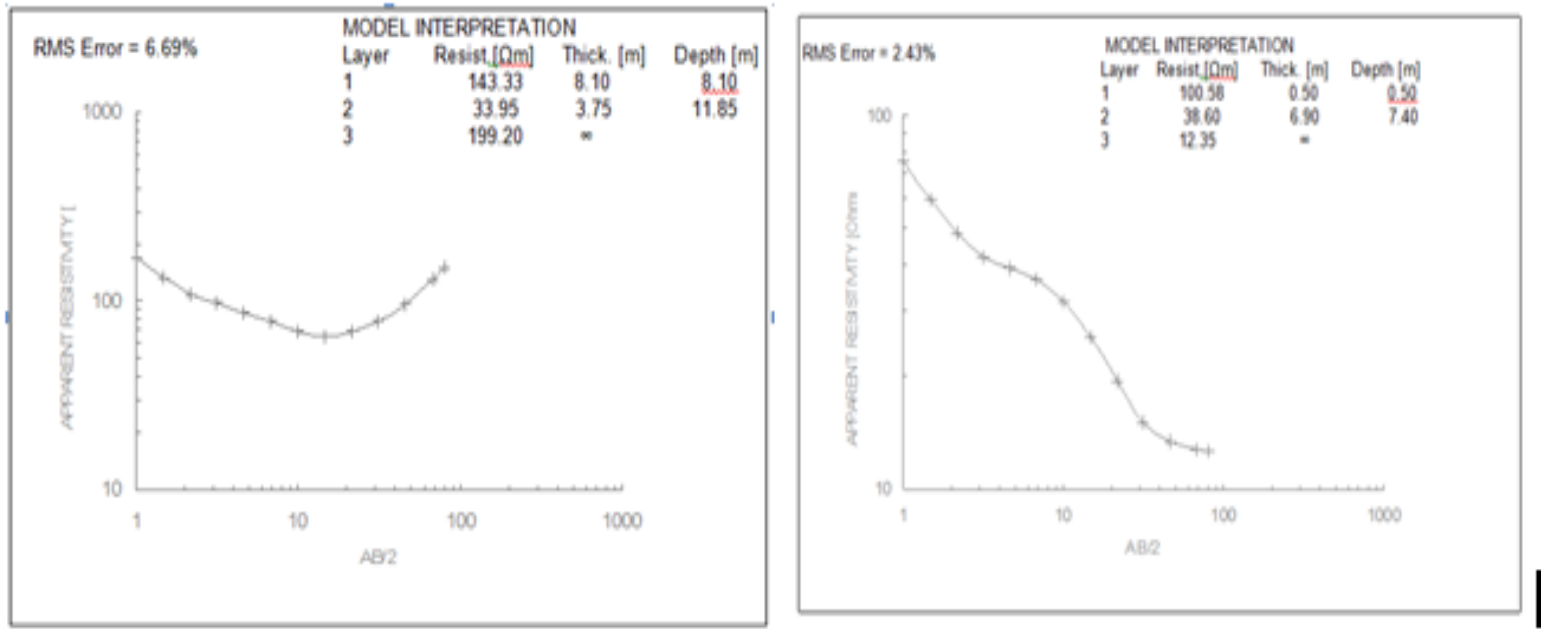

Figure 2. Showing FCD-3 and FCD-4 (from left to right)
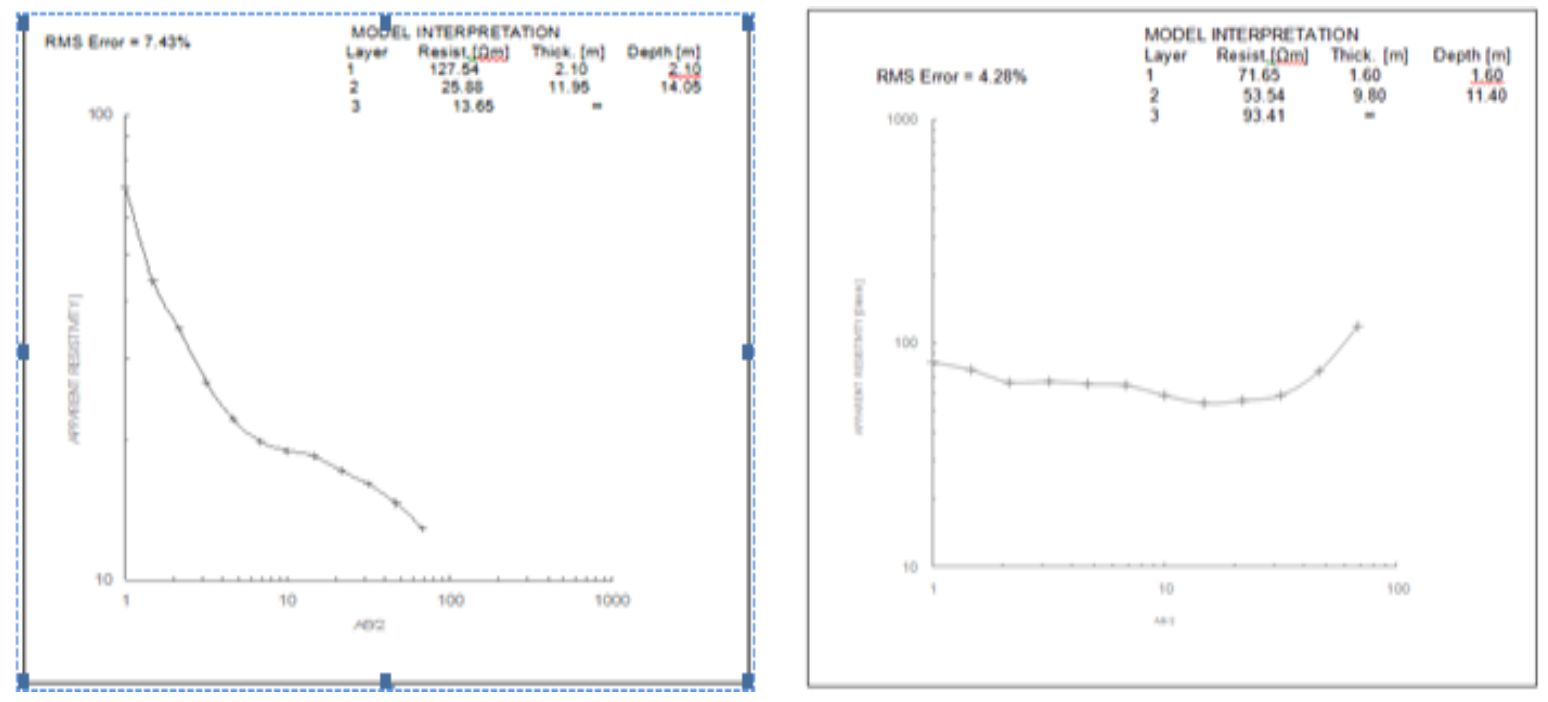

Figure 3. Showing FCD-5and FCD-6 (from left to right) 


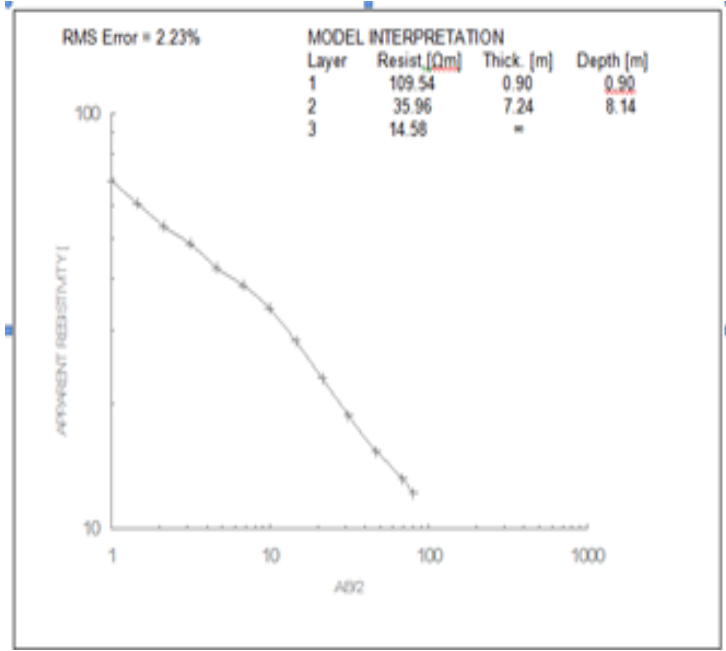

Figure 4. Showing FCD-7 and FCD-8 (from left to right)

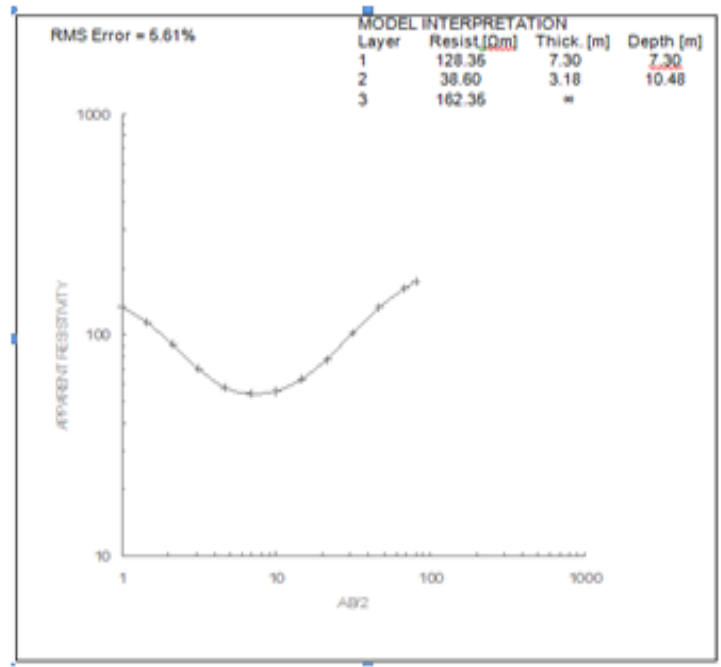

Figure 5. Showing FCD-9 and FCD-10 (from left to right)

method. Ten grammes of a representative soil sample were extracted with $20 \mathrm{ml}$ of toluene. The absorbance of the toluene extract was then measured with the aid of a spectrophotometer at $420 \mathrm{~nm}$ wavelength. The spectrophotometer reading was then converted to parts per million (ppm) by reference to a standard curve, which was prepared using known concentrations of hydrocarbons in the extractant. Heavy metals in soil were determined by the perchloric acid digestion method as described by Udo (1986). The filtrate was then used for the determination of heavy metals by atomic absorption spectrophotometry.

\section{Ground water data collection}

The direction of ground water movement within the bund walls of each tank was determined from both the three or
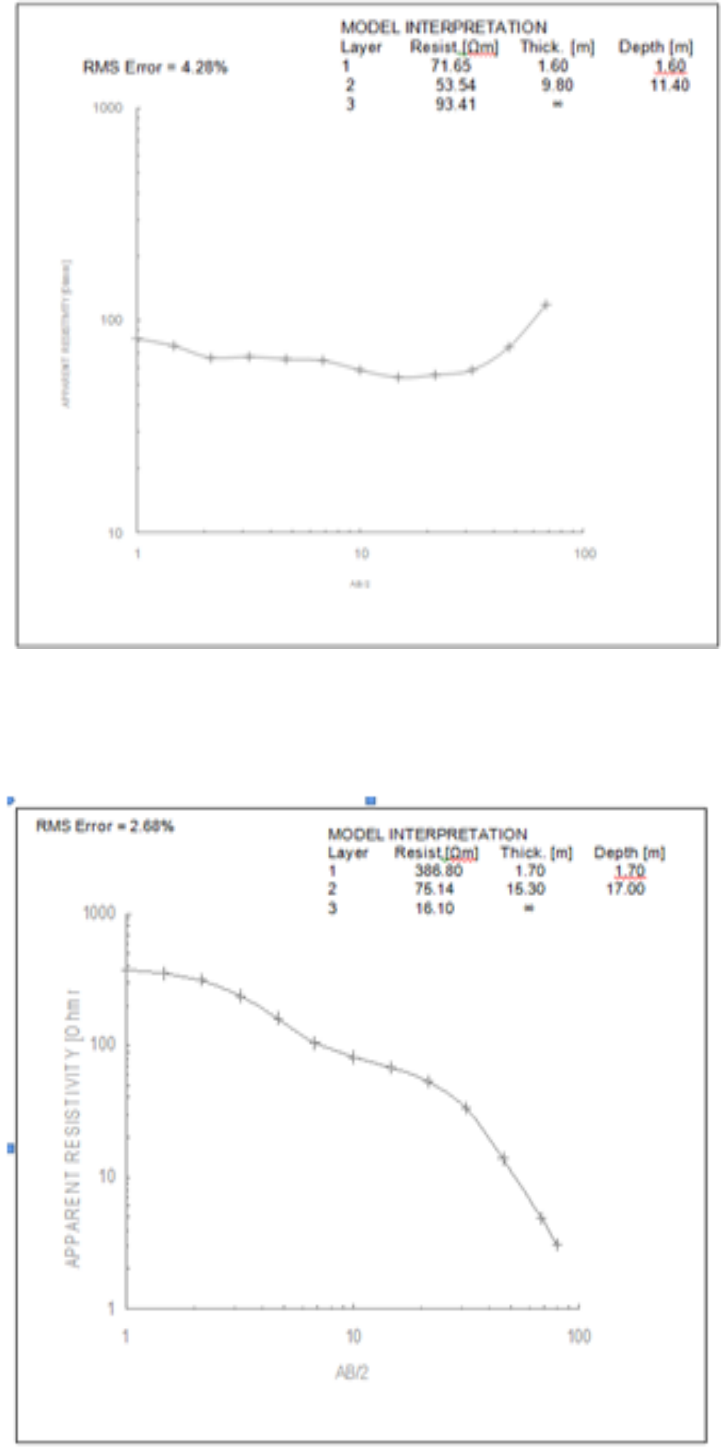

four monitoring boreholes drilled and the contour lines of the water table map (potentiometric surface map) of the area. To ensure the accuracy and reliability of in situ field measurements, all field instruments were calibrated before use. The depth of static water level and total well depth was measured with a graduated weighted line and recorded in a field parameters form.

All wells were purged before sampling with Teflon pump. Samples collected were preserved in accordance with DPR guidelines Part VII-D.DPR recommended methods from ASTM, USEPA and APHA were used. Standard laboratory quality control procedures were adhered to for the analysis of the water samples. These included determination of reagent blanks, use of fresh standards and replicate analysis for confidence limit, and cleaning of glass wares and other containers. Samples for hydrocarbon determination analysis were similarly treated. 
Physico-chemical studies of 18 monitoring wells were conducted. In each of the monitoring wells, composite water samples were taken with use of hose pump that was wash thoroughly and rinsed with distilled water. The samples were analyzed to produce a groundwater database for the required parameters. Water samples were collected for laboratory analysis for Total petroleum hydrocarbons (TPH), BTEX and major cation and anion elements. In situ field measurements of $\mathrm{pH}$, conductivity and temperature were made at the field. The water samples temperatures were determined in situ using a mercury-in-glass thermometer. $\mathrm{pH}$ was determined in situ using a Hach-One $\mathrm{pH}$ Meter. Conductivity was measured in situ using a Hach Portable conductivity meter. Dissolved oxygen (DO) was determined by the Schott Gerate dissolved oxygen meter using the membrane electrode method. Biochemical Oxygen Demand (BOD), which depends on oxygen uptake by bacteria, was determined using the dilution method according to APHA507. Iron was determined colorimetrically by the very sensitive ferrozine method of the Hach spectrophotometer. Phosphorus as reactive orthophosphate was determined using the stannous chloride method specially suited for determining low amounts of phosphate concentrations. The low range nitrate test employed in the analysis of water was the Hach modification of the cadmium reduction method, using a very sensitive chromotropic acid indicator. The procedure employed to determine sulphate was a modification of the barium sulphate turbidimetric method using the Hach equipment. Sodium and potassium were analyzed by flame photometry. For zinc, copper, nickel, lead, chromium, cadmium, mercury, cobalt and nickel, flame atomic absorption spectrophotometry was used. Total hydrocarbon in the water sample was extracted with $\mathrm{CCl}_{4}$ at $\mathrm{pH} 5$ and the concentration was deduced from the calibration graph using the "Quant Software. Total Petroleum Hydrocarbon (TPH) was determined by Infra Red (IR) Spectrophotometry- ASTM D3921. Bezene, Toluene, Ethylene and Xylene (BTEX) were determined using DPR recommended methods from ASTM, USEPA and APHA.

\section{RESULTS AND DISCUSSIONS}

\section{Vertical Electrical sounding investigation (VES)}

As a first step, the apparent resistivity data were plotted against half-electrode spacing on bilogarithmic paper. An initial interpretation was done using the manual curve matching technique to obtain a model for the area. This served as a quality check to eliminate field anomalies. Layer parameters were subsequently derived for this initial model and used in the computer-assisted interpretation.

The geo-electrical field data was fed into the computer using a specialized software (ABEM Super-VES) to obtain the resistivity of the near subsurface and then iteratively interpret the data employing digital filters and subsequently plot the VES curves (as shown in figures 1 -5). Root Mean Square (RMS) errors of between 2.23 and $8.11 \%$ were achieved.

The response curve for the ten VES stations is shown in figure 1 to 5 above and table 1 show all VES GPS points, number of resistivity and thickness of layers, depth to bottom of layers and curve types. Iterative computer interpretations indicate a three geo-electric layer model case for all the curves.

The first VES station (FCD-1) depicts an H-type curve (Figure1-left) and shows apparent resistivity ranging from $19.35 \Omega \mathrm{m}$ to $175.70 \Omega \mathrm{m}$. The first geo-electric layer is being interpreted as sandy water-saturated topsoil, which is about $7.5 \mathrm{~m}$ thick, with an apparent resistivity of $64.63 \Omega \mathrm{m}$. This relatively low apparent resistivity value is likely due to the brackish nature of the water. Underlying the topsoil is a $4.7 \mathrm{~m}$ thick, lower apparent resistivity $(19.35 \Omega \mathrm{m})$ formation, interpreted a brackish-water saturated sandy material, with higher salinity than the topsoil. The third geo-electric layer is believed to be a sandy lithology of apparent resistivity in excess of $175.70 \Omega \mathrm{m}$. The response curve for FCD-2 is depicted in figure 1-right with a Q-type curve. Iterative computer interpretation gave a best-fit three-layer model with low apparent resistivity values ranging from $13.02 \Omega \mathrm{m}$ to $82.08 \Omega \mathrm{m}$. The first geo-electric layer is interpreted as $0.43 \mathrm{~m}$ thick sandy topsoil with apparent resistivity of $82.08 \Omega \mathrm{m}$. The middle layer is a $5.84 \mathrm{~m}$ thick, lower apparent resistivity layer, interpreted as a brackish water saturated sand lithology. The third geo-electric layer is a sandy material with an even lower apparent resistivity value of $13.12 \Omega \mathrm{m}$. This low value is attributable to the presence of saline water.

The curve response for FCD-3 (figure 2-left) is an $\mathrm{H}$ type. The computer iteration gave a three-layered model with $8.1 \mathrm{~m}$ thick sandy topsoil having an apparent resistivity value of $143.33 \Omega \mathrm{m}$. The second geo-electrical layer, $3.75 \mathrm{~m}$ thick, is interpreted as a sandy horizon saturated with brackish-water $(33.95 \Omega \mathrm{m})$ and the third depicts a sandy horizon with apparent resistivity of $199.20 \Omega \mathrm{m}$. The response curve of FCD-4 (figure 2-right) is a $Q$ type and its Iterative computer interpretation gave a three-layer model with low apparent resistivity values ranging from $12.35 \Omega \mathrm{m}$ to $100.58 \Omega \mathrm{m}$. The first geoelectric layer is interpreted as $0.5 \mathrm{~m}$ thick sandy topsoil with apparent resistivity of $100.58 \Omega \mathrm{m}$. The topsoil is underlain by a $6.9 \mathrm{~m}$ thick, lower apparent resistivity layer, interpreted as a brackish water saturated sand lithology. The third geo-electric layer is a sandy material with an even lower apparent resistivity value of $12.35 \Omega \mathrm{m}$. This low value is attributable to the presence of saline water.

FCD-5 (figure 3-left) gave a curve response of an $\mathrm{H}$ type. The computer iteration gave a three-layered model with $1.3 \mathrm{~m}$ thick sandy topsoil having an apparent 
70 Int. Res. J. Geol. Min.

Table 1: showing VES GPS points, number of derived resistivity and thickness of layers, depth to bottom of layers and curve types.

\begin{tabular}{|c|c|c|c|c|c|c|c|c|c|c|c|c|c|}
\hline \multicolumn{4}{|c|}{ VES location } & \multicolumn{3}{|c|}{$\begin{array}{c}\text { Number of resistivity of } \\
\text { layers }(\Omega \mathrm{m})\end{array}$} & \multicolumn{3}{|c|}{$\begin{array}{l}\text { Thickness of layers } \\
(\mathrm{m})\end{array}$} & \multicolumn{3}{|c|}{$\begin{array}{l}\text { Depth to bottom } \\
\text { of layers }(m)\end{array}$} & \multirow[t]{2}{*}{$\begin{array}{c}\text { Curve } \\
\text { type }\end{array}$} \\
\hline $\mathbf{N}$ & Code & Nothings & Eastings & $\rho_{1}$ & $\rho_{2}$ & $\rho_{3}$ & $t_{1}$ & $t_{2}$ & $t_{3}$ & $d_{1}$ & $d_{2}$ & $d_{3}$ & \\
\hline$\hat{1}$ & FCD-1 & $\begin{array}{l}\text { N05 } \\
20.714\end{array}$ & $\begin{array}{l}E 005^{\circ} \\
20.948^{\circ}\end{array}$ & 64.63 & 19.35 & 175.70 & 7.5 & 4.7 & $\infty$ & 7.5 & 12.20 & - & $\mathrm{H}$ \\
\hline 2 & FCD-2 & $\begin{array}{l}\text { N05 } \\
20.681^{\circ}\end{array}$ & $\begin{array}{l}E 005^{\circ} \\
21.261^{\text {. }}\end{array}$ & 82.08 & 40.3 & 13.2 & 0.43 & 5.84 & $\infty$ & 0.43 & 6.27 & - & Q \\
\hline 3 & FCD-3 & $\begin{array}{l}\mathrm{N}^{\circ} 5^{\circ} \\
20.635^{\prime}\end{array}$ & $\begin{array}{l}E 005^{\circ} \\
20.925^{\circ}\end{array}$ & $\begin{array}{c}143.3 \\
3\end{array}$ & 33.95 & 199.20 & 8.10 & 3.75 & $\infty$ & 8.10 & 11.85 & - & $\mathrm{H}$ \\
\hline 4 & FCD-4 & $\mathrm{N}^{\circ} 5^{\circ} 20.58^{\circ}$ & $\begin{array}{l}E 005^{\circ} \\
21.133^{\circ}\end{array}$ & $\begin{array}{c}100.5 \\
8\end{array}$ & 38.60 & 12.35 & 0.50 & 6.90 & $\infty$ & 0.50 & 7.40 & - & Q \\
\hline 5 & FCD-5 & $\begin{array}{l}\text { N05 } \\
20.5297^{\circ}\end{array}$ & $\begin{array}{l}\mathrm{E} 005^{\circ} \\
20.900^{\prime}\end{array}$ & 41.25 & 55.41 & 309.99 & 1.30 & 10.50 & $\infty$ & 1.30 & 11.80 & - & $\mathrm{H}$ \\
\hline 6 & FCD-6 & $\begin{array}{l}\text { N05 } \\
20.458\end{array}$ & $E 005^{0} 21.119$ & $\begin{array}{c}127.5 \\
4\end{array}$ & 25.88 & 113.65 & 2.10 & 11.95 & $\infty$ & 2.10 & 14.05 & - & Q \\
\hline 7 & FCD-7 & $\begin{array}{l}\text { N05 } \\
20.442\end{array}$ & $\begin{array}{l}\text { E005 } \\
20.877^{\circ}\end{array}$ & 71.65 & 53.54 & 93.41 & 1.60 & 9.80 & $\infty$ & 1.60 & 11.40 & - & $\mathrm{H}$ \\
\hline 8 & FCD-8 & $\begin{array}{l}\text { N05 } \\
20.442\end{array}$ & $\begin{array}{l}E 005^{\circ} \\
21.094^{\circ}\end{array}$ & $\begin{array}{c}109.5 \\
4\end{array}$ & 35.96 & 14.58 & 0.90 & 7.24 & $\infty$ & 0.90 & 8.14 & - & Q \\
\hline 9 & FCD-9 & $\begin{array}{l}\text { N05 } \\
20.391\end{array}$ & $\begin{array}{l}E 005^{\circ} \\
20.582\end{array}$ & $\begin{array}{c}128.3 \\
5\end{array}$ & 38.60 & 162.35 & 7.30 & 3.18 & $\infty$ & 7.30 & 10.48 & - & $\mathrm{H}$ \\
\hline 10 & FCD-10 & $\begin{array}{l}\text { N05 } \\
20.349^{\circ}\end{array}$ & $\begin{array}{l}E 005^{\circ} \\
21.082^{\circ}\end{array}$ & $\begin{array}{c}386.8 \\
0\end{array}$ & 75.14 & 16.10 & 1.70 & 15.30 & $\infty$ & 1.70 & 17.00 & - & $Q$ \\
\hline
\end{tabular}

resistivity value of $141.25 \Omega \mathrm{m}$. The second geo-electrical layer, $10.5 \mathrm{~m}$ thick, is interpreted as a brackish-water saturated sandy horizon $(55.41 \Omega \mathrm{m})$ and the third depicts a sandy horizon with apparent resistivity of $309.99 \Omega$ m.FCD-6 (figure 3-right) shows the response curve as a Q-type. The curve reflects a three-layer system. The topmost geo-electric layer is a2.1m thick sandy topsoil while the second is brackish-water-laden sand, $11.95 \mathrm{~m}$ thick. Geo-electric layer 3 is a saline-water saturated sandy horizon with apparent resistivity of $13.65 \Omega \mathrm{m}$.

FCD-7 (figure 4-left) is an $\mathrm{H}$ type curve and resulted in a three-layered model with $1.6 \mathrm{~m}$ thick sandy topsoil having an apparent resistivity value of $71.65 \Omega \mathrm{m}$. The middle geo-electrical layer, $9.80 \mathrm{~m}$ thick, is interpreted as a brackish-water saturated sandy horizon $(53.54 \Omega \mathrm{m})$ and the third depicts a sandy horizon with apparent resistivity of $93.41 \Omega \mathrm{m} . \mathrm{FCD}-8$ (figure 4-right) shows a Q-type response curve. Iteration gave a three-layer system. The first geo-electric layer is $0.9 \mathrm{~m}$ thick sandy topsoil while the second is brackish-water-laden sand, $7.24 \mathrm{~m}$ thick. Geo-electric layer 3 is a saline-water saturated sandy horizon with apparent resistivity of $14.58 \Omega \mathrm{m}$.

The interpretation result of station FCD-9 (figure 5-left) gave an $\mathrm{H}$-type curve. Iteration gave a three-layered model with $7.3 \mathrm{~m}$ thick sandy topsoil having an apparent resistivity value of $128.35 \Omega \mathrm{m}$. The second geo-electrical layer, $3.18 \mathrm{~m}$ thick, is interpreted as a brackish-water saturated sandy horizon $(38.60 \Omega \mathrm{m})$ and the third depicts a sandy horizon with apparent resistivity of $162.35 \Omega \mathrm{m}$. The response curve for station FCD-10 (figure 5-right) is a Q-type. The computer iteration gave a three-layer system. The first geo-electric layer is $1.7 \mathrm{~m}$ thick sandy topsoil while the second is brackish-waterladen sand, $15.3 \mathrm{~m}$ thick. Geo-electric layer 3 is a salinewater saturated sandy horizon with apparent resistivity of $16.1 \Omega \mathrm{m}$.

Based on the result analysis above; we thus infer that the lithology of the study area is predominantly sandy which conforms to literature. The responses from the geo-electric surveys conducted at the tank farm gave geo-electric layers that depict homogenous layers of sand laden with water of varying saline concentration.

Although brackish and saline waters show low resistivity values, an increase in the number of ions in soil water due to groundwater contamination further decreases the soil resistivity. The depths penetrated define sand thicknesses of approximately $15 \mathrm{~m}$. For instance, FCD-1 probed $12.2 \mathrm{~m}$ with maximum current electrode spacing of $68.1 \mathrm{~m}$ while FCD-4 reached a depth of $7.4 \mathrm{~m}$ with a current electrode spread of $80 \mathrm{~m}$. Station FCD-5 stations investigated down to $11.8 \mathrm{~m}$ with a spread of $100 \mathrm{~m}$ while FCD-10 probed deepest to $17 \mathrm{~m}$ with a current electrode spread of $80 \mathrm{~m}$. Depth to brackish water-saturated horizon varied between 0 and $2.1 \mathrm{~m}$. Generally, the soundings from tanks $2,4,6,8$ and 10 reflect similar readings while tanks $1,3,5,7$ and 9 also reflect similar curves. With the absence of clayey horizons, groundwater contamination is very likely to be placing the natural balance of the ecosystem at risk. 
Table 2. showing soil samples analysis at tank 1,2 and 3

\begin{tabular}{|c|c|c|c|c|c|c|c|c|c|c|}
\hline \multirow{2}{*}{$\frac{\text { Well name }}{\text { Well location }}$} & \multicolumn{3}{|l|}{ Tank 1} & \multicolumn{3}{|c|}{ Tank 2} & \multicolumn{4}{|l|}{ Tank3 } \\
\hline & TK1 & TK1 & TK1 & TK2 & TK2 & TK2 & TK3 & TK3 & TK3 & TK3 \\
\hline & BH1 & BH2 & BH3 & BH1 & BH2 & BH3 & BH1 & BH2 & BH3 & $\mathrm{BH} 4$ \\
\hline \multicolumn{11}{|c|}{ Core sample analysis } \\
\hline $\mathrm{pH}\left(\right.$ in $\left.\mathrm{H}_{2} \mathrm{O}\right)$ & 5.82 & 5.77 & 5.69 & 5.89 & 6.02 & 5.85 & 5.83 & 5.75 & 6.02 & 5.45 \\
\hline Av.P(meq/100g)) & 1.82 & 1.11 & 0.95 & 0.85 & 1.32 & 1.55 & 1.76 & 1.85 & 1.8 & 1.22 \\
\hline $\mathrm{NO}_{3}{ }^{2-}($ meq $/ 100 \mathrm{~g})$ & 2.90 & 3.11 & 2.75 & 2.86 & 3.06 & 1.98 & 3.34 & 3.55 & 2.83 & 2.79 \\
\hline $\mathrm{SO}_{4}{ }^{2-}$ (meq/100g) & 1.16 & 1.28 & 1.46 & 0.99 & 1.18 & 1.67 & 2 & 2.45 & 0.67 & 0.83 \\
\hline $\mathrm{K}$ (meq /100g) & 3.00 & 2.65 & 3.46 & 3.22 & 4.78 & 4.38 & 2.14 & 3.29 & 4.89 & 5.11 \\
\hline $\mathrm{Fe}(\mathrm{meq} / 100 \mathrm{~g}$ & 42.61 & 34.67 & 47.98 & 52.9 & 41.34 & 42.96 & 38.58 & 45.89 & 50.57 & 34.88 \\
\hline $\mathrm{Cu}(\mathrm{meq} / 100 \mathrm{~g}$ & 0.12 & 0.08 & 0.15 & 0.22 & 0.26 & 0.15 & 0.31 & 0.24 & 0.22 & 0.18 \\
\hline $\mathrm{Ni}^{+}(\mathrm{Meq} / 100 \mathrm{~g})$ & 0.01 & 0.01 & 0.02 & 0.01 & 0.01 & 0.02 & 0.01 & $<0.01$ & $<0.01$ & $<0.01$ \\
\hline $\mathrm{Pb}^{+}($Meq/100g) & $<0.01$ & $<0.01$ & $<0.01$ & 0.02 & $<0.01$ & $<0.01$ & 0.02 & 0.01 & 0.04 & 0.01 \\
\hline $\mathrm{Zn}^{+}(\mathrm{Meq} / 100 \mathrm{~g})$ & 1 & 1.51 & 2 & 1 & 2.35 & 3 & 2.23 & 2.43 & 1.34 & 1.45 \\
\hline Cr (meq/100g) & 0.01 & 0.02 & 0.01 & 0.02 & 0.02 & 0.02 & 0.01 & 0.04 & 0.01 & 0.01 \\
\hline Ba (meq/100g) & 0.01 & 0.02 & 0.02 & 0.01 & 0.02 & 0.01 & 0.02 & 0.01 & 0.01 & 0.02 \\
\hline O\&G(meq/100g) & 0.09 & 0.12 & 0.01 & 0.20 & 0.08 & $<0.01$ & 0.06 & 0.02 & 0.11 & 0.02 \\
\hline TPH(meq/100g) & 0.13 & 0.21 & 0.04 & 0.02 & 0.06 & 0.18 & 0.26 & 1.21 & 0.45 & 0.01 \\
\hline
\end{tabular}

Table 3. Showing soil samples analysis at tank 4 and 5

\begin{tabular}{|c|c|c|c|c|c|c|c|c|c|c|c|}
\hline \multirow{3}{*}{$\begin{array}{l}\text { Well name } \\
\text { Well location }\end{array}$} & \multicolumn{4}{|l|}{ Tank 4} & \multicolumn{7}{|l|}{ Tank5 } \\
\hline & TK4 & TK4 & TK4 & TK4 & TK5 & TK5 & TK5 & TK5 & TK5 & TK5 & TK5 \\
\hline & BH1 & BH2 & ВH3 & $\mathrm{BH} 4$ & BH1 & BH2 & BH3 & BH4 & BH5 & BH6 & BH7 \\
\hline \multicolumn{12}{|c|}{ Core sample analysis } \\
\hline $\mathrm{pH}\left(\right.$ in $\left.\mathrm{H}_{2} \mathrm{O}\right)$ & 5.66 & 5.89 & 6.11 & 5.94 & 5.79 & 5.85 & 5.70 & 5.55 & - & - & - \\
\hline Av.P(meq/100g)) & 0.56 & 0.49 & 0.63 & 1.69 & 1.06 & 1.1 & 1.31 & 1.02 & - & - & - \\
\hline $\mathrm{NO}_{3}{ }^{2-}($ meq $/ 100 \mathrm{~g})$ & 2.94 & $2 . .65$ & 3.55 & 2.9 & 2.54 & 2.11 & 1.93 & 1.42 & - & - & - \\
\hline $\mathrm{SO}_{4}^{2-}(\mathrm{meq} / 100 \mathrm{~g})$ & 1.34 & 1.54 & 1.86 & 2.33 & 2.76 & 1.87 & 1.75 & 1.92 & - & - & - \\
\hline K (meq /100g) & 3.99 & 3.34 & 2.89 & 4.66 & 3.78 & 4.56 & 3.89 & 4.25 & - & - & - \\
\hline Fe(meq /100g & 43.17 & 43.56 & 35.76 & 35.67 & 46.75 & 44.25 & 57.67 & 42.55 & - & - & - \\
\hline Cu(meq/100g & 0.23 & 0.34 & 0.28 & 0.34 & 0.51 & 0.06 & 0.35 & 0.62 & - & - & - \\
\hline $\mathrm{Ni}^{+}(\mathrm{Meq} / 100 \mathrm{~g})$ & 0.01 & 0.01 & 0.01 & 0.01 & 0.01 & 0.02 & $<0.01$ & $<0.01$ & - & - & - \\
\hline $\mathrm{Pb}^{+}(\mathrm{Meq} / 100 \mathrm{~g})$ & $<0.01$ & $<0.01$ & $<0.01$ & $<0.01$ & $<0.01$ & 0.03 & 0.02 & 0.01 & - & - & - \\
\hline $\mathrm{Zn}^{+}(\mathrm{Meq} / 100 \mathrm{~g})$ & 1 & 3.34 & 2.22 & 1 & 1 & 1.45 & 1.26 & 1.55 & - & - & - \\
\hline Cr (meq/100g) & 0.01 & 0.03 & 0.01 & 0.04 & 0.01 & 0.02 & 0.01 & 0.02 & - & - & - \\
\hline Ba (meq/100g) & 0.01 & 0.02 & 0.03 & 0.02 & 0.01 & 0.03 & 0.02 & 0.01 & - & - & - \\
\hline O\&G(meq/100g) & $<0.01$ & $<0.01$ & 0.25 & $<0.01$ & 0.53 & 1.03 & 1.42 & 0.73 & - & - & - \\
\hline TPH(meq/100g) & 1.26 & 0.06 & 0.04 & 0.06 & 2.36 & 1.42 & 0.88 & 1.03 & - & - & - \\
\hline
\end{tabular}

\section{Stratigraphy}

The stratigraphy (Lithologs) of the underlying formation of all the monitoring boreholes $(\mathrm{BH})$ drilled within the bund walls of the storage tanks were determined through direct observation and interpretation of data obtained from boring, core samples tests and laboratory sieving results. Core samples of depths $0.0 \mathrm{~m}-1.5 \mathrm{~m}$ were collected from each of the monitoring boreholes drilled within the bund walls and analysed for their physico-chemical characteristics. The physical and chemical characteristics of soil strata overlying aquifers may impact the groundwater. Contaminants form plumes in soil environment and can be leached down subsurface materials to contaminate the underlying unconfined aquifer. Notwithstanding the fact that soil undergoes attenuation to get rid of contaminants, underlying groundwater can still become contaminated when the appropriate soil chemical and biophysical conditions for the process are not present (USEPA 2004). The results of the physico-chemical characteristics of the core soil samples are shown in tables 2, 3,4 and 5. Field studies and laboratory analytical results showed that the soils of the borehole cuttings are predominantly sandy. The soil 
72 Int. Res. J. Geol. Min.

Table 4. Showing soil samples analysis at tank 6,7 , and 8

\begin{tabular}{|c|c|c|c|c|c|c|c|c|c|c|c|c|}
\hline \multirow{3}{*}{$\frac{\text { Well name }}{\text { Well location }}$} & \multicolumn{4}{|l|}{ Tank 6} & \multicolumn{4}{|l|}{ Tank7 } & \multicolumn{4}{|l|}{ Tank8 } \\
\hline & TK6 & TK6 & TK6 & TK6 & TK7 & TK7 & TK7 & TK7 & TK8 & TK8 & TK8 & TK8 \\
\hline & BH1 & $\mathrm{BH} 2$ & $\mathrm{BH} 3$ & $\mathrm{BH} 4$ & BH1 & $\mathrm{BH} 2$ & $\mathrm{BH} 3$ & $\mathrm{BH} 4$ & BH1 & $\mathrm{BH} 2$ & $\mathrm{BH} 3$ & $\mathrm{BH} 4$ \\
\hline \multicolumn{13}{|c|}{ Core sample analysis } \\
\hline $\mathrm{pH}\left(\right.$ in $\left.\mathrm{H}_{2} \mathrm{O}\right)$ & 5.75 & 5.66 & 5.91 & 6.05 & 5.85 & 5.20 & 5.84 & 5.92 & 5.74 & 5.31 & 6.11 & 5.61 \\
\hline Av.P(meq/100g)) & 0.67 & 0.88 & 0.95 & 1.25 & 1.63 & 1.85 & 1.94 & 2.05 & 1.56 & 1.71 & 1.01 & 0.73 \\
\hline $\mathrm{NO}_{3}{ }^{2-}(\mathrm{meq} / 100 \mathrm{~g})$ & 2.86 & 3.22 & 3.15 & 2.58 & 2.68 & 1.95 & 2.53 & 2.22 & 2.32 & 1.85 & 2.32 & 2.08 \\
\hline $\mathrm{SO}_{4}^{2-}(\mathrm{meq} / 100 \mathrm{~g})$ & 0.75 & 1.11 & 0.92 & 1.33 & 2.89 & 2.67 & 2.74 & 2.46 & 2.64 & 1.23 & 1.84 & 1.55 \\
\hline $\mathrm{K}($ meq $/ 100 \mathrm{~g})$ & 3.45 & 3.22 & 3.15 & 2.56 & 2.67 & 4.24 & 3.69 & 4.88 & 4.93 & 4.27 & 4.22 & 3.33 \\
\hline $\mathrm{Fe}(\mathrm{meq} / 100 \mathrm{~g}$ & 54.67 & 31.89 & 35.78 & 43.67 & 45.56 & 43.11 & 35.36 & 46.67 & 35.56 & 30.67 & 42.58 & 46.22 \\
\hline $\mathrm{Cu}(\mathrm{meq} / 100 \mathrm{~g}$ & 0.42 & 0.27 & 0.35 & 0.26 & 0.51 & 0.48 & 0.58 & 0.61 & 0.66 & 0.54 & 0.46 & 0.38 \\
\hline $\mathrm{Ni}^{+}(\mathrm{Meq} / 100 \mathrm{~g})$ & $<0.01$ & $<0.01$ & $<0.01$ & $<0.01$ & 0.01 & 0.01 & 0.01 & 0.01 & 0.01 & 0.01 & 0.01 & 0.01 \\
\hline $\mathrm{Pb}^{+}(\mathrm{Meq} / 100 \mathrm{~g})$ & 0.02 & 0.01 & 0.02 & 0.01 & $<0.01$ & $<0.01$ & $<0.01$ & $<0.01$ & $<0.01$ & $<0.01$ & $<0.01$ & $<0.01$ \\
\hline $\mathrm{Zn}^{+}(\mathrm{Meq} / 100 \mathrm{~g})$ & $<0.01$ & $<0.01$ & $<0.01$ & $<0.01$ & 1 & 1 & 1 & 1.22 & 1.31 & 1 & 1 & 1.21 \\
\hline $\mathrm{Cr}(\mathrm{meq} / 100 \mathrm{~g})$ & 0.01 & 0.04 & 0.02 & 0.01 & 0.01 & 0.02 & 0.03 & 0.01 & 0.02 & 0.01 & 0.02 & 0.01 \\
\hline $\mathrm{Ba}(\mathrm{meq} / 100 \mathrm{~g})$ & $<0.01$ & $<0.01$ & $<0.01$ & $<0.01$ & 0.01 & 0.01 & 0.01 & 0.02 & 0.02 & 0.01 & 0.02 & 0.01 \\
\hline $\mathrm{O} \& \mathrm{G}(\mathrm{meq} / 100 \mathrm{~g})$ & 0.05 & 0.01 & 0.07 & 0.11 & 0.03 & 0.03 & $<0.01$ & $<0.01$ & 0.01 & 0.02 & 0.01 & $<0.01$ \\
\hline $\mathrm{TPH}(\mathrm{meq} / 100 \mathrm{~g})$ & 0.01 & 0.22 & 0.05 & 0.04 & 0.34 & 0.27 & 1.01 & 0.26 & 0.08 & 0.18 & 0.05 & 0.77 \\
\hline
\end{tabular}

Table 5. showing soil samples analysis at tank 9 and 10

\begin{tabular}{|c|c|c|c|c|c|c|c|}
\hline \multirow{2}{*}{$\frac{\text { Well name }}{\text { Well location }}$} & \multicolumn{4}{|l|}{ Tank9 } & \multicolumn{3}{|c|}{ Tank 10} \\
\hline & TK9 & TK9 & TK9 & TK9 & TK10 & TK10 & TK10 \\
\hline & BH1 & BH2 & BH3 & BH4 & BH1 & BH2 & BH3 \\
\hline \multicolumn{8}{|c|}{$\underline{\text { Core sample analysis }}$} \\
\hline $\mathrm{pH}\left(\right.$ in $\left.\mathrm{H}_{2} \mathrm{O}\right)$ & 5.67 & 5.72 & 5.46 & 5.78 & 5.83 & 6.13 & 5.72 \\
\hline Av.P(meq/100g)) & 0.88 & 0.59 & 1.82 & 1.95 & 1.72 & 2.04 & 1.75 \\
\hline $\mathrm{NO}_{3}{ }^{2-}(\mathrm{meq} / 100 \mathrm{~g})$ & 2.33 & 2.46 & 3.42 & 3.05 & 2.78 & 2.89 & 2.45 \\
\hline $\mathrm{SO}_{4}{ }_{4}^{2-}(\mathrm{meq} / 100 \mathrm{~g})$ & 2.03 & 3.54 & 2.66 & 2.98 & 2.54 & 1.37 & 3.25 \\
\hline K (meq /100g) & 2.84 & 4.37 & 3.54 & 2.45 & 4.23 & 2.55 & 3.44 \\
\hline $\mathrm{Fe}(\mathrm{meq} / 100 \mathrm{~g}$ & 39.56 & 38.68 & 42.58 & 40.23 & 38.46 & 43.45 & 40.37 \\
\hline $\mathrm{Cu}(\mathrm{meq} / 100 \mathrm{~g}$ & 0.71 & 0.46 & 0.52 & 0.72 & 0.57 & 0.25 & 0.31 \\
\hline $\mathrm{Ni}^{+}(\mathrm{Meq} / 100 \mathrm{~g})$ & 0.02 & 0.02 & 0.01 & 0.01 & 0.01 & 0.01 & $<0.01$ \\
\hline $\mathrm{Pb}^{+}(\mathrm{Meq} / 100 \mathrm{~g})$ & 0.01 & 0.02 & $<0.01$ & $<0.01$ & $<0.01$ & $<0.01$ & 0.02 \\
\hline $\mathrm{Zn}^{+}(\mathrm{Meq} / 100 \mathrm{~g})$ & 1.02 & 1.13 & 1 & 1.11 & 1.22 & 1 & 1.04 \\
\hline Cr (meq/100g) & 0.03 & 0.04 & 0.01 & 0.01 & 0.02 & 0.01 & 0.02 \\
\hline $\mathrm{Ba}(\mathrm{meq} / 100 \mathrm{~g})$ & 0.02 & 0.03 & 0.01 & 0.01 & 0.01 & 0.01 & 0.02 \\
\hline O\&G(meq/100g) & 0.22 & 0.16 & 0.05 & 0.04 & 0.13 & $<0.01$ & 0.16 \\
\hline TPH(meq/100g) & 0.01 & 0.02 & $<0.01$ & 0.23 & 0.35 & $<0.01$ & 0.29 \\
\hline
\end{tabular}

samples are acidic. The $\mathrm{pH}$ values ranged from 5.206.11 . The acidic nature of the soil samples could serve as good medium for the dissolution of heavy metals in the soil. Soil nitrate content of the cuttings ranged from 1.42 $-3.55 \mathrm{meq} / 100 \mathrm{~g}$. Available phosphorus values ranged from $0.49 \mathrm{meq} / 100 \mathrm{~g}$ to $2.05 \mathrm{meq} / 100 \mathrm{~g}$. Potassium content ranged from $2.14-4.93 \mathrm{meq} / 100 \mathrm{~g}$. Heavy metals contents of the core samples were low, except for iron concentrations which ranged from $31.89 \mathrm{meq} / 100 \mathrm{~g}$ $54.67 \mathrm{meq} / 100 \mathrm{~g}$, while, zinc concentrations ranged from $<0.01-3.34 \mathrm{meq} / 100 \mathrm{~g}$. Copper, nickel, lead, chromium, and barium concentrations of the soil core samples were low; they ranged from below detectable limit to $0.04 \mathrm{meq} / 100 \mathrm{~g}$. Oil and grease and TPH contents ranged from $<0.01-3.36 \mathrm{meq} / 100 \mathrm{~g}$.

\section{Groundwater}

Tables 6 and 7 below show some of the results of the physical-chemical analysis of water samples at selected tank site. The hydrogen ion concentrations $(\mathrm{pH})$ of the ground water samples were slightly basic. This explains the significant presence of some heavy metals in the samples analyzed. This is because basic environment could serves as good medium for dissolution of some heavy metals just as acidic environment does to some heavy metals. The total suspended solid concentrations 
Table 6. Showing groundwater samples analysis at tank 1, 2 and 3

\begin{tabular}{|c|c|c|c|c|c|c|c|c|c|c|}
\hline \multirow{3}{*}{$\frac{\text { Well name }}{\text { Well location }}$} & \multicolumn{3}{|l|}{ Tank 1} & \multicolumn{3}{|l|}{ Tank 2} & \multicolumn{4}{|l|}{ Tank3 } \\
\hline & TK1 & TK1 & TK1 & TK2 & TK2 & TK2 & TK3 & TK3 & TK3 & TK3 \\
\hline & BH1 & BH2 & BH3 & BH1 & BH2 & BH3 & BH1 & BH2 & BH3 & BH4 \\
\hline \multicolumn{11}{|c|}{ Groundwater sample analysis } \\
\hline $\mathrm{PH}$ & 7.8 & 7.4 & 7.1 & 7.6 & 7.8 & 7.6 & 7.4 & 7.4 & 7.7 & 7.6 \\
\hline $\operatorname{Ec}(\mathrm{uS} / \mathrm{cm})$ & 3030 & 2745 & 3008 & 2623 & 1784 & 2960 & 2930 & 795 & 1583 & 1239 \\
\hline TDS(mgll) & 1553 & 2076 & 1569 & 1894 & 2346 & 1514 & 1495 & 1899 & 674 & 1057 \\
\hline $\operatorname{TSS}(\mathrm{mg} / \mathrm{l})$ & 9.5 & 11.3 & 8.8 & 23 & 7.9 & 14 & 14 & 17 & 19.5 & 24 \\
\hline $\mathrm{DO}(\mathrm{mg} / \mathrm{l})$ & 2 & 1.89 & 3.45 & 4.2 & 3.55 & 1.1 & 1 & 1.55 & 2.45 & 2.66 \\
\hline $\mathrm{BOD}_{5}(\mathrm{mg} / \mathrm{l})$ & 5.65 & 7.7 & 5.9 & 2 & 5.75 & 19.5 & 28.25 & 9.7 & 7.3 & 11.8 \\
\hline \multicolumn{11}{|l|}{ Cations } \\
\hline $\mathrm{Na}(\mathrm{mg} / \mathrm{l})$ & 90.996 & 48.008 & 78.911 & 88.233 & 65.871 & 46.205 & 68.6 & 45.121 & 67.987 & 117.129 \\
\hline $\mathrm{K}(\mathrm{mg} / \mathrm{l})$ & 2.059 & 21.93 & 17.113 & 35.934 & 5.098 & 0.968 & 49.074 & 25.765 & 29.896 & 35.879 \\
\hline $\mathrm{Ca}(\mathrm{mg} / \mathrm{l})$ & 49.08 & 44.823 & 54.776 & 34.023 & 25.678 & 5.56 & 28.44 & 31.789 & 27.987 & 12.879 \\
\hline $\mathrm{Mg}(\mathrm{mg} / \mathrm{l})$ & 55.56 & 43.389 & 17.846 & 26.889 & 23.773 & 28.02 & 62.64 & 44.795 & 20.789 & 56.89 \\
\hline $\mathrm{Cu}(\mathrm{mg} / \mathrm{l})$ & 0.013 & 0.031 & 0.017 & 0.015 & 0.021 & 0.012 & 0.015 & 0.019 & 0.031 & 0.011 \\
\hline $\mathrm{Fe}(\mathrm{mg} / \mathrm{l})$ & 1.285 & 0.896 & 2.367 & 2.086 & 1.671 & 2.257 & 1.902 & 1.734 & 0.892 & 1.347 \\
\hline \multicolumn{11}{|l|}{ Anions } \\
\hline $\mathrm{NO}_{3}-\mathrm{N}(\mathrm{mg} / \mathrm{l})$ & 2.17 & 1.89 & 2.06 & 2.44 & 1.67 & 3.52 & 4.92 & 2.35 & 2.63 & 2.34 \\
\hline Av.P(mg/l) & 0.04 & 0.04 & 0.11 & 0.08 & 0.03 & 0.1 & 0.12 & 0.22 & 0.13 & 0.27 \\
\hline $\mathrm{TP}(\mathrm{mg} / \mathrm{l})$ & 0.05 & 0.06 & 0.19 & 0.12 & 0.07 & 0.13 & 0.14 & 0.37 & 0.33 & 0.4 \\
\hline $\mathrm{SO}_{4}(\mathrm{mg} / \mathrm{l})$ & 21.3 & 26.21 & 25 & 19.33 & 24.11 & 31.57 & 24.15 & 25.43 & 21.22 & 25.45 \\
\hline $\mathrm{Cl}^{-}(\mathrm{mg} / \mathrm{l})$ & 999.69 & 894.45 & 910.55 & 954.22 & 1045.34 & 974.7 & 1034.68 & 689.65 & 1237.48 & 765.72 \\
\hline \multicolumn{11}{|l|}{ Heavy metals } \\
\hline $\mathrm{Ni}$ & 0.007 & 0.009 & 0.013 & 0.004 & 0.009 & 0.018 & 0.012 & 0.022 & 0.006 & 0.015 \\
\hline $\mathrm{Pb}$ & 0.67 & 0.236 & 0.089 & 0.277 & 0.118 & 0.73 & 0.631 & 0.476 & 0.092 & 0.175 \\
\hline $\mathrm{Cd}$ & $<0.001$ & 0.003 & $<0.001$ & $<0.001$ & 0.002 & $<0.001$ & 0.005 & 0.003 & 0.006 & $<0.001$ \\
\hline $\mathrm{Cr}$ & 1.483 & 0.785 & 1.112 & 1.445 & 0.796 & 1.495 & 2.053 & 2.124 & 0.477 & 0.49 \\
\hline $\mathrm{Hg}$ & $<0.001$ & $<0.001$ & $<0.001$ & $<0.001$ & $<0.001$ & $<0.001$ & $<0.001$ & $<0.001$ & $<0.001$ & $<0.001$ \\
\hline As & $<0.001$ & $<0.001$ & $<0.001$ & 0.012 & $<0.001$ & $<0.001$ & $<0.001$ & $<0.001$ & $<0.001$ & $<0.001$ \\
\hline $\begin{array}{l}\text { Total AliphaticHC } \\
\text { Polynuclear }\end{array}$ & 0.120 & 0.231 & 0.089 & 0.108 & 0.079 & 0.053 & 0.112 & 0.157 & 0.049 & 0.037 \\
\hline AromaticHC(PAH) & 0.039 & 0.021 & 0.006 & 0.067 & 0.051 & 0.044 & 0.071 & 0.015 & 0.042 & 0.026 \\
\hline TotalPetroleum & & & & & & & & & & \\
\hline $\mathrm{HC}(\mathrm{TPH})$ & 0.159 & 0.252 & 0.095 & 0.175 & 0.13 & 0.097 & 0.183 & 0.172 & 0.091 & 0.063 \\
\hline
\end{tabular}


74 Int. Res. J. Geol. Min.

Table 7. Ground water samples analysis at tank 9 and 10

\begin{tabular}{|c|c|c|c|c|c|c|c|}
\hline \multirow{2}{*}{$\begin{array}{l}\text { Well name } \\
\text { Well location }\end{array}$} & \multicolumn{2}{|c|}{ Tank 9} & \multicolumn{5}{|c|}{ Tank 10} \\
\hline & $\overline{T K S}$ & TK9 & TK9 & TK9 & TK10 & TK10 & TK10 \\
\hline & $\mathrm{BH}$ & $\mathrm{BH} 2$ & $\mathrm{BH} 3$ & $\mathrm{BH} 4$ & $\mathrm{BH} 1$ & $\mathrm{BH} 2$ & $\mathrm{BH} 3$ \\
\hline \multicolumn{8}{|c|}{ Groundwater sample analysis } \\
\hline $\mathrm{pH}$ & 7.6 & 7.3 & 7.8 & 7.6 & 7.6 & 7.3 & 7.8 \\
\hline Ec (uS/cm) & 5431 & 6580 & 4378 & 765 & 634 & 1458 & 4539 \\
\hline TDS(mg/l) & 3216 & 3480 & 1987 & 505 & 308 & 1221 & 3487 \\
\hline $\mathrm{TSS}(\mathrm{mg} / \mathrm{l})$ & 22.67 & 18.5 & 25 & 35.6 & 52 & 30.8 & 40 \\
\hline $\mathrm{DO}(\mathrm{mg} / \mathrm{l})$ & 1.9 & 2.7 & 2.1 & 2.2 & 0.4 & 3.1 & 2.6 \\
\hline $\mathrm{BOD}_{5}(\mathrm{mg} / \mathrm{l})$ & 8.1 & 27.1 & 25.5 & 27.9 & 3.4 & 26.6 & 25.9 \\
\hline $\mathrm{Na}(\mathrm{mg} / \mathrm{l})$ & 104.789 & 158.181 & 67.897 & 85.661 & 102.193 & 83.775 & 93.445 \\
\hline $\mathrm{K}(\mathrm{mg} / \mathrm{l})$ & 45.006 & 53.771 & 66.256 & 17.87 & 47.226 & 14.567 & 27.179 \\
\hline $\mathrm{Ca}(\mathrm{mg} / \mathrm{l})$ & 55.551 & 65.76 & 39.085 & 18.996 & 39.76 & 6.889 & 36.779 \\
\hline $\mathrm{Mg}(\mathrm{mg} / \mathrm{l})$ & 121.345 & 149.76 & 89.345 & 97.256 & 140.94 & 134.125 & 156.782 \\
\hline $\mathrm{Cu}(\mathrm{mg} / \mathrm{l})$ & 0.016 & 0.022 & 0.019 & 0.022 & 0.021 & 0.018 & 0.013 \\
\hline $\mathrm{Fe}(\mathrm{mg} / \mathrm{l})$ & 5.778 & 3.208 & 4.236 & 3.776 & 8.807 & 5.231 & 2.421 \\
\hline $\mathrm{NO}_{3}-\mathrm{N}(\mathrm{mg} / \mathrm{l})$ & 3.65 & 4.22 & 3.45 & 2.88 & 3.69 & 3.21 & 2.75 \\
\hline Av.P(mg/l) & 0.14 & 0.09 & 0.22 & 0.18 & 0.1 & 0.05 & 0.05 \\
\hline $\mathrm{TP}(\mathrm{mg} / \mathrm{l})$ & 0.18 & 0.11 & 0.26 & 0.24 & 0.16 & 0.9 & 0.12 \\
\hline $\mathrm{SO}_{4}(\mathrm{mg} / \mathrm{l})$ & 24.15 & 5.04 & 9.77 & 18.35 & 24.15 & 21.33 & 19.55 \\
\hline $\mathrm{Cl}^{-}(\mathrm{mg} / \mathrm{l})$ & 2879.55 & 2249.30 & 345.56 & 278.00 & 77.47 & 2368.24 & 1177.83 \\
\hline $\mathrm{Ni}$ & 0.011 & 0.031 & 0.019 & 0.044 & $<0.001$ & 0.08 & 0.016 \\
\hline $\mathrm{Pb}$ & 0.028 & 0.384 & 0.279 & 0.119 & 0.009 & 0.011 & 0.067 \\
\hline $\mathrm{Cd}$ & $<0.001$ & 0 & 0.005 & 0.003 & 0.009 & $<0.001$ & $<0.001$ \\
\hline $\mathrm{Cr}$ & 0.568 & 1.376 & 2.007 & 2.234 & 1.387 & 0.543 & 0.234 \\
\hline $\mathrm{Hg}$ & $<0.001$ & $<0.001$ & $<0.001$ & $<0.001$ & $<0.001$ & $<0.001$ & $<0.001$ \\
\hline As & $<0.001$ & 0.046 & 0.021 & 0.007 & $<0.001$ & $<0.001$ & 0.003 \\
\hline Total AliphaticHC & 0.231 & 0.106 & 0.120 & 0.231 & 0.049 & 0.128 & 0.068 \\
\hline $\begin{array}{l}\text { Polynuclear } \\
\text { AromaticHC(PAH) }\end{array}$ & 0.075 & 0.030 & 0.021 & 0.041 & 0.082 & 0.031 & 0.078 \\
\hline $\begin{array}{l}\text { TotalPetroleum } \\
\text { HC(TPH) }\end{array}$ & 0.306 & 0.136 & 0.141 & 0.272 & 0.13 & 0.159 & 0.146 \\
\hline
\end{tabular}

were above the World Health Organisation (WHO) recommended value for portable water. This is an indication of the ground water pollution probably at low level. This is further substantiated by the high concentrations of $\mathrm{BOD}_{5}$ values for groundwater potability.

Sodium, calcium, and potassium concentrations in most of the boreholes were significantly above 10ppm, which exceeds the regulatory limits. This could be trace to various activities been carried out since the inception of the facility. Iron concentration in the water samples ranged from $0.07 \mathrm{ppm}-18.72 \mathrm{ppm}$, a range which is of public health importance in portable water. This level is above the regulatory limit of $1.0 \mathrm{ppm}$. Literature revealed that naturally, the Niger-Delta soil has high concentrations of iron. Operational activities over the years in this study facility could also attribute to these high concentrations of iron in the ground water. Nickel, lead, arsenic and chromium concentrations range from $<0.001-2.728 \mathrm{ppm}$, which are in line with acceptable standards.

The VES and stratigraphy study revealed that the soil structure of the study area is predominantly sandy. Sandy 
Soil is loose in structure. This implies that spillage or discharge of contaminants into the study area can easily percolate into the ground water as the soil has low holding capacity. In contrast, Total Petroleum Hydrocarbon (TPH) concentrations ranged from 0.011$0.441 \mathrm{mg} / \mathrm{l}$ while benzene, toluene, ethyl benzene, and xylene concentrations were all below detection limits. This suggests that there has not been major leakage(s) of crude oil from the storage tanks into the groundwater Or there is prompt recovery and remediation strategy used in the environmental management of these facilities.

\section{CONCLUSIONS}

The study revealed that the natural subsurface materials of the soil within bund walls of the storage tanks are predominantly sandy. The subsurface soil materials have relatively high permeability. The near subsurface lithology of the investigated area as revealed by the apparent resistivity interpretation acquired from the VES stations is made up of sand that is saturated with brackish to saline water. No clay or sandy clay layer was inferred, implying that there is no layer to act as a buffer against any contamination that may be produced from the crude oil storage tanks, thus impairing the groundwater.

The groundwater flow direction of the area within the bund walls in each of the tanks is from the North to the Southern direction. This implies that, if the groundwater system in this area is contaminated, then water in the Southern part will be most affected.

The physico-chemical parameters concentrations in the ground water revealed that some were above the permissible limits stipulated by the Federal Ministry of Environment, and Department of Petroleum Resources. By World Health Organisation's (WHO) standards, the concentrations of anions, cations and heavy metals in the water samples indicated that the quality of the ground water in its present state does not make the ground water potable and can present a health risk concern to people within and around the facility, if used for domestic purposes. Therefore, routine monitoring and effective remediation of the soil or ground water contaminated as result of the activities within the facility should be given prompt and adequate attention for improved environmental management system.

\section{REFERENCES}

Abdullahi NK, Osazuwa IB, Sule PO, (2011). Application of integrated geophysical technique in the investigation of groundwater contamination: A case study of Municipal solid waste leachate. Ozean J. Applied Scie, 4:7-25

Adeoti L, Alilie OM, Uchegbulam O (2010). Geophysical investigation of saline water intrusion into freshwater aquifers;A case study of Oniru, Lagos state. Sci. Res. Essays, 5: 248-259

Ahilan J, Kumar GRS (2011). Identification of aquifer zones by VES method: A case study from Mangalore block, Tamil Nadu, S. India.
Arch. Applied Sci. Res., 3:414-421

Akaninyen OA, Igbokwe MU (2011). Monitoring Groundwater contamination using surface electrical resistivity and geochemical methods. J. Water Resources and Protection.

Ariyo SO, Adeyemi GO (2009). Role of resistivity method for ground water exploration in hard rock areas: a case study from Fidiwo/ Ajebo Areas of south-western Nigeria: Pacific J. Sci. Technol. 10:483-486

Armada LT, Dimanlanta CB,. Yumul Jr. GP, Tamayo Jr. RA (2009). Georesistivity signature of crystalline rock in the Romblon Island Group, Philippines: Philippine J. Sci, 138:191-204

Bray RH, Kurtz LT (1945). Determination of Total Organic and Available Forms of Phosphorus in Soils. Soil Science. 59

Chapman: Water Quality Assessments - A Guide to Use of Biota, Sediments and Water in

Cid-Fernandez JA, Araujo PA (2007). VES characterization of a geothermal area in the NW of Spain. EIEAF Che., 6:2173-2177

Dingman SL (2002). Physical hydrology, Second edition. New Jersey, Prentice Hall, Upper Saddle River

Egbai JC (2011). Vertical electrical sounding for the determination of aquifer transmissivity. Aust. J. Basic Applied Sci., 5:1209-1214

Ekwe AC, Nnodu IN, Ugwumbah KI, Onwuka OS (2010). Estimation of aquifer hydraulic characteristics of low permeability formation from geo-sounding data: A case study of Oduma Town, Enugu State. Online J. Earth Sci., 4:19-26

Enikanselu PA (2008). Detection of monitoring of dumpsite- induced groundwater contamination using electrical resistivity method Pac. J. Sci. Technol., 9:254-262

Environmental Monitoring - Second Edition, (c) UNESO/WHO/UNEP, 1992

Fetter CW (1994). Applied Hydrology $3^{\text {rd }}$ edition, Prentice Hall.

George NJ, Obianwu, Obot IB (2011). Estimation of groundwater reserve in unconfined frequently exploited depth of aquifers using combined superficial geophysical and laboratory techniques in the Niger Delta, South-South, Nigeria. Adv. Applied Sci. Res., 2:163-177

Hodlur GK, Dhakatea R, Sirisha T, Panaskar DB (2010). Resolution of freshwater and saline water aquifers by composite geophysical data analysis methods. Hydrol. Sci. J., 55:414-434

Joshua EO, Odeyemi OO, Fawehinmi OO (2011). Geoelectric investigation of the groundwater potential of Moniya Area, Ibadan. J. Goel.Min.Res., 3;54-62

K' Orowe MO, Nyadawa MO, Siingh VS, Ratnakar D (2011). Hydrogeophysical parameter estimation for aquifer characterization in hard rock environments: A case study from Jangaon sub-watershed, India. J.Oceanogr. Mar. Sci., 2:50-62

Majumdar RK, Das D (2011). Hydrological characterization and estimation of aquifer properties from electrical sounding data in Saga Island region, South 24 Parganas, West Bengal, India Asian J. Earth Scie., 4:60-74

Nejad HT (2009). Geo-electric investigation of the aquifer characteristics and groundwater potential in Behbahan Azad University Farm, Khuzestan Province, Iran. J. Applied Sci., 9:36913698

Nwanwkwo LI (2011). 2D resistivity survey for groundwater exploration in a hard rock terrain: A case study of MAGDAS observatory, UNILORIN, Nigeria. Asian J.Earth Sci., 4:46-53

Okareh OT (2006). Monitoring wells installation and ground water quality assessment in an oil and gas exploration industry. Pp 1-42.

Onu NN (2003). Estimates of the relative specific yield of aquifer from geo-electrical sounding data of the coastal plains of south eastern Nigeria. J. Technol. Educ. Nig., 8:69-83

Short KC, Stauble AJ (1967). Outline Geology of the Niger Delta. AAPG Bull. Vol. 51, pp 761-779.

Sikandar P, Bakhsh A, Ali T (2010). Vertical electrical sounding (VES) resistivity survey technique to explore low salinity groundwater for tube well installation in Chaj Doab. J. Agric. Res., 48:547-566

Telford W, Geldart L, Sherrif R, Keys D (1976). Applied Geophysics. Cambridge University Press. Pp 680

Tizro AT, Voudouris KS, Salehzade M, Mashayekhi H (2010). Hydro geological framework and estimation of aquifers hydraulic parameters using geo-electrical data: A case study of west Iran. Hdrogeol. J. 18 917-929 
76 Int. Res. J. Geol. Min.

Ugwu SA, Nwosu JI (2009). Effects of Waste Dumps on Ground in Choba Using Geophysical Method. J. Applied Sci. Environ. Manage. 130:85-89

UNEP GEMS water programme): Water Quality Outlook (ISBN 9503911-4)

USEPA (2004). United State Environmental protection Agency, 2004

Wigwe GA (1975). The Niger Delta: Physical. In G.E.K. Ofomata (ed).
Nigeria in maps: Eastern States. Pp380 -400. Ethiope Publ. House, Benin City

World Health Organization (1984). Guidelines and Standard for Potable Water Quality

Zohdy, A.A.R., G.P. Eaton and D.R. Mabey, 1974. Application of Surface Geophysics to Groundwater Investigations. Techniques of Water Resources Investigations of the USGS, Chapter D1, pp: 5-62 